\title{
Physicochemical characteristics, viability of starters, total phenolics and antioxidant activities of functional yoghurt supplemented with extracts from Hylocereus polyrhizus, Hibiscus sabdariffa and Peristrophe bivalvis
}

\author{
Nguyen Phuoc Minh \\ Faculty of Food Science and Technology, Thu Dau Mot University, Binh Duong Province, Vietnam \\ *Email: nguyenphuocminh@tdmu.edu.vn
}

\section{ARTICLE HISTORY}

Received: 29 October 2020

Accepted: 04 January 2021

Published: 15 January 2021

\section{KEYWORDS}

Antioxidant

Hibiscus sabdariffa

Hylocereus polyrhizus

Peristrophe bivalvis

Phenolics

Physicochemical activity

Yoghurt

\section{ABSTRACT}

Hylocereus polyrhizus, Hibiscus sabdariffa and Peristrophe bivalvis contain a great source of anthocyanin with excellent antioxidant property. Consumers highly appreciate the Yoghurt enriched with phenolics originated from plant. This research evaluated the possibility of yoghurt incorporated with pigment extract from Hylocereus polyrhizus, Hibiscus sabdariffa and Peristrophe bivalvis. Total acidity, syneresis, viability of starter culture, total phenolic content, free radical-scavenging activity of the enriched yoghurt were observed. Results showed that there was significant difference of total acidity, syneresis among yoghurt samples. Meanwhile there were a dramatic increasing of viability of starter culture, total phenolic content, free radical-scavenging activity in the enriched yoghurt compared to the control. Lactobacillus acidophilus retained high viability during storage due to functional prebiotic of plant extracts. Hibiscus sabdariffa extract would be a promising alternative for the enriched yoghurt with better health benefits.

\section{Introduction}

Hylocereus polyrhizus is extensively cultivated in Southeast Asia. H. polyrhizus fruit is rich in lycopene, anthocyanin, flavanoid, antioxidants and phytoalbumins (1-5). Its peel occupied $20-25 \%$ of the fruit with a great source of phenolics especially betalain but it is usually discarded as waste (6-8). Its peel can be utilized and converted into value-added product by pigment extraction. It can be considered as the natural food colorants not only healthy for human body, but also friendly for society and environment (911). Hibiscus sabdariffa is one of underutilized ornamental plants widely distributed in the subtropical and tropical regions of West, East Africa and South-East Asia. H. sabdariffa calyx has beautiful unique anthocyanin pigment with high antioxidant properties (12-14). Its flower contains valuable phytochemical bioactive constituents like phenolics, flavonoids, vitamins greatly contributing to different therapeutic advantages to cure hypertension, hyperlipidemia, cancer and inflammatory diseases; mild the blood viscosity; stimulate milk release and induce intestinal peristalsis (15-18). It's commonly utilized as purple dye for colouring and flavouring agent to enhance the flavour, aroma and overall acceptance of wine, syrup, juice, jam, jelly, pudding, cake, ice cream, tea, confectionery, sauce, marmalade, chocolate (14, 19-27). Peristrophe bivalvis is a herbaceous perennial plant widely distributed in cool and humid climate areas (28). It has numerous colors like purple, purple-magenta, red and yellow (29). It contains different photosynthetic pigments, anthocyanins, phenolics, flavonoids. It's useful in food, biological and pharmaceutical industries. It has various therapeutic functions such as antihypertension, anti-hyperlipidemia, fungistatic, antibacterial, antioxidant (30-33).

Lactobacillus acidophilus is a gram [+] bacteria with rod morphology, approximately $2-10 \mu \mathrm{m}$ in dimension. L. acidophilus is homofermentative in

(c) Minh (2021). This is an open-access article distributed under the terms of the Creative Commons Attribution License, which permits unrestricted use, distribution and reproduction in any medium, provided the original author and source are credited (https://creativecommons.org/licenses/by/4.0/).

To cite this article: Minh N P. Physicochemical characteristics, viability of starters, total phenolics and antioxidant activities of functional yoghurt supplemented with extracts from Hylocereus polyrhizus, Hibiscus sabdariffa and Peristrophe bivalvis. Plant Science Today. 2021;8(1):149-154. https://doi.org/10.14719/pst.2021.8.1.1009 
glycolysis to ferment hexoses and produce $\mathrm{D}$ and $\mathrm{L}$ lactic acids (34). It grows well at $30-45{ }^{\circ} \mathrm{C}$ and $\mathrm{pH} 4-5$ to produce a great amount of lactic acid, some acetic acid with no hydrogen and no catalase (35). $L$. acidophilus is proved to possess various beneficial effects against health disorders. It has ability to prevent blood cholesterol, mutagenicity, carcinogenicity, constipation, diarrhea, lactose intolerance $(36,37)$. It's commonly used in the meat, milk, fruits, vegetables and cereal products (38). Yoghurt is a probiotic carrier originated from fermentation of milk. Yoghurt is nutritionally rich in available proteins, minerals, vitamins (39, 40). Yoghurt is extremely superior to milk, specially for people facing lactose intolerance because lactose has been converted to lactic acid by the bacterial starter culture $(41,42)$. Yoghurt also has useful functional application as probiotic carrier against gastro intestinal disorders $(39,43)$. Yoghurt can improve gum health, facilitate calcium absorption, limit osteoporosis (44). There has a great demand of symbiotic yoghurt containing prebiotics and probiotics to boost human health and well-being. Different literatures mentioned to yoghurt production enriched by numerous phytochemical sources such as coconut (45), spirulina (46), dietary fiber (47), date (48), milk protein (49), strawberry pulp (50), apple pomace flour (51), artichoke flour (52), olive fruit polyphenol (53), soy bean flour (54), $H$. sabdariffa (55), H. polyrhizus (56). Yoghurts are prepared in various styles and varieties (57). However there was any report mentioned to the utilization of $P$. bivalvis to enrich yoghurt. Objective of our study was to examine the possibility of yoghurt incorporated with various pigment extracts from $H$. polyrhizus, $H$. sabdariffa and $P$. bivalvis.

\section{Materials and Methods}

\section{Material}

Pasteurized milk and skim milk powder were purchased from grocery store. $H$. sabdariffa (Roselle), $H$. polyrhizus (red pitaya), $P$. bivalvis (magenta plant) were collected from January to June of 2018 in local gardens of Ke Sach district, Soc Trang province, Vietnam. They were kept in fresh and quickly moved to laboratory for experiments. Lactobacillus acidophilus from Vinmec was kept at $20{ }^{\circ} \mathrm{C}$ during transportation and utilized as starter culture for Yoghurt fermentation. Chemical reagents were all analytical grade.

\section{Researching method}

$H$. sabdariffa calyx, $H$. polyrhizus fruit pulp and $P$. bivalvis leaf materials were preliminary dried by convective drying at $50{ }^{\circ} \mathrm{C}$ to $18 \%$ moisture content and extracted by ethanol $70 \%$ (at ratio 1:3, material: solvent) by hot extraction and then evaporated under a rotary concentrator to get pigment extracts. 1000 $\mathrm{mL}$ of pasteurized milk and $250 \mathrm{gm}$ of skim milk powder were primarily mixed together. 5 gm of $H$. sabdariffa, $H$. polyrhizus and $P$. bivalvis pigment extracts were individually added into the prepared mixture. This mixture was heated at $85{ }^{\circ} \mathrm{C}$ for 20 minutes and cooled to $43.5{ }^{\circ} \mathrm{C}$ before adding $0.1 \% \mathrm{~L}$. acidophilus (12 log colony forming unit/g or cfu/gm) as starter culture. The incubation was conducted at $43.5{ }^{\circ} \mathrm{C}$ for $8 \mathrm{hrs}$ to produce yoghurt. The control group was similarly prepared as the above protocol without pigment extracts. All manufactured yoghurt samples were all examined total acidity, syneresis, viability of starter culture, total phenolic content, free radical-scavenging activity.

\section{Physicochemical, microbial and antioxidant determination}

Total acidity (\%w/w lactic acid) was estimated by titration with $0.1 \mathrm{~N} \mathrm{NaOH}$ using phenolphthalein as an indicator. Syneresis (\%) was evaluated by draining $50 \mathrm{ml}$ of unstirred yoghurt spread evenly on filter paper at $4{ }^{\circ} \mathrm{C}$ for $6 \mathrm{hrs}$. The obtained whey volume multiplied by 2 was considered as syneresis (58). Viability of $L$. acidophilus (log cfu/gm) was enumerated by 3M-Petrifilm protocol (59). Total phenolic content (mg gallic acid equivalent/ $100 \mathrm{gm}$ or mg GAE/ $100 \mathrm{gm}$ ) was examined by the FolinCiocalteu protocol (60). Free radical-scavenging activity (\%,DPPH) was determined by 2,2 diphenyl-1picrylhydrazyl supporting by UV/Vis spectrophotometer (60).

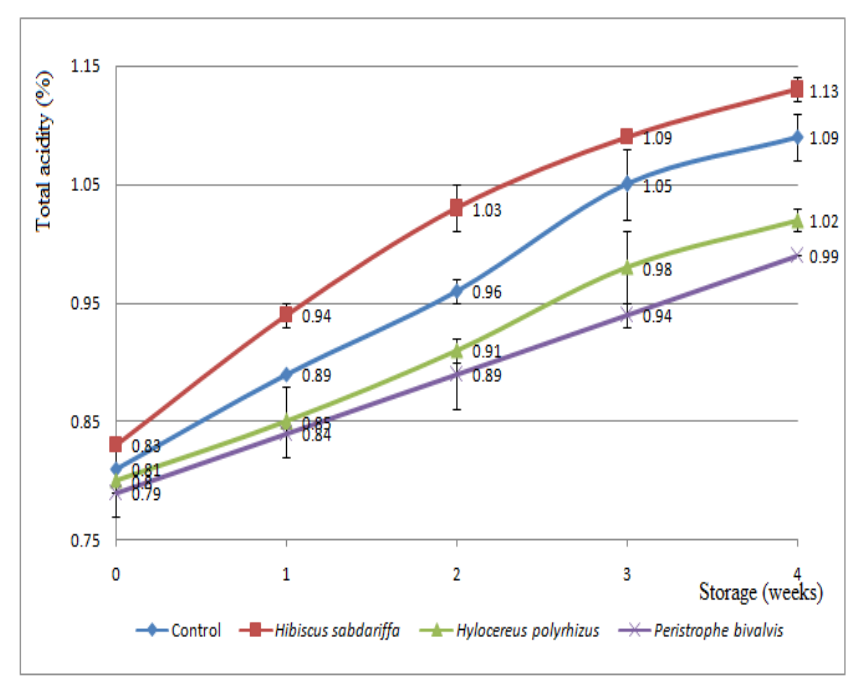

Fig. 1. Total acidity (\% w/w) of yoghurt enriched by Hibiscus sabdariffa, Hylocereus polyrhizus, Peristrophe bivalvis extracts.

\section{Results and Discussion}

Fig. 1 shows the effect of $H$. sabdariffa, $H$. polyrhizus, $P$. bivalvis extracts on the total acidity of the enriched yoghurt. Total acidity had an increasing trend during storage. During the fermentation of milk into yogurt, the high metabolic activity of yogurt bacteria decreased with cooling whereas enzymatic activity continued. Hence, an accumulation of total acidity was noticed during storage (61). Yogurt supplemented with $H$. sabdariffa had the highest total acidity $(0.83 \div 1.13 \%)$. Meanwhile the yoghurt incorporated with $P$. bivalvis had the lowest total acidity $(0.79 \div 0.99 \%)$. This may be attributed to the higher acidity of $H$. sabdariffa extract compared to other ones. According to one study, total acidity of $H$. sabdariffa extract was $4.20 \pm 0.01 \%$ (in fresh calyx), $12.73 \pm 0.09 \%$ (in concentrated fresh roselle extract) 
and $11.96 \pm 0.34 \%$ (in concentrated dried roselle extract) (62). Supplementation of $H$. sabdariffa calyx extract into the reconstituted low fat milk yoghurt resulted in significant reduction of $\mathrm{pH} 4.4 \div 4.16$ vs. $4.54 \div 4.31$ as control (63). H. sabdariffa L. flowers marmalade significantly increased titratable acidity of formulated yoghurt (64). Addition of $H$. sabdariffa calyx extract into the probiotic yoghurt resulted to total acidity $0.81 \div 1.14 \%$ (65). Yogurts enriched by $H$. polyrhizus resulted a higher lactic acid percentage $(1.14 \div 1.23 \%)$ compared to plain yogurt (1.08\%) (56).

Fig. 2 presented the influence of $H$. sabdariffa, $H$. polyrhizus and $P$. bivalvis extract on the syneresis of the enriched yoghurt. Syneresis had an increasing trend during storage. Yogurt supplemented with $H$. sabdariffa had the highest syneresis (30.4-9.3\%). Meanwhile the control yoghurt had the lowest

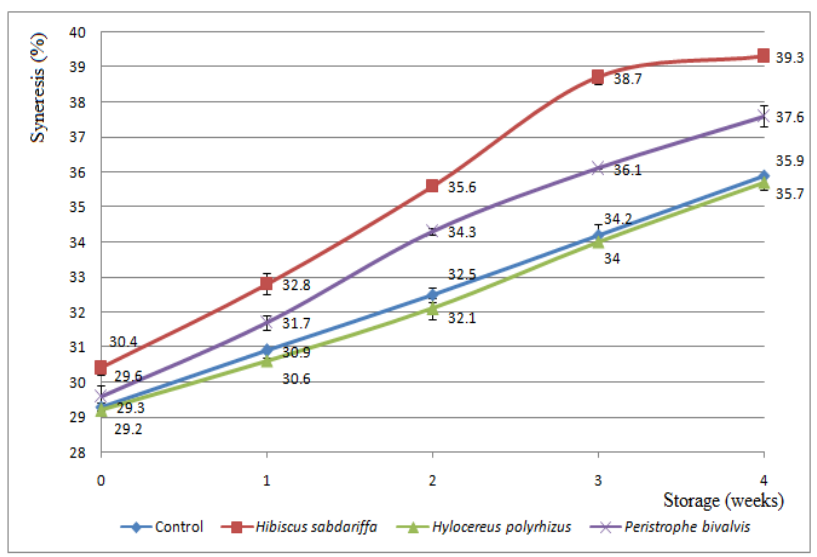

Fig. 2. Syneresis (\% w/w) of yoghurt enriched by Hibiscus sabdariffa, Hylocereus polyrhizus, Peristrophe bivalvis extracts.

syneresis (29.3-5.9\%). Addition of $H$. sabdariffa calyx extract into the reconstituted low fat milk yoghurt resulted in significant reduction of syneresis 0.8-1.9 vs. 1.3-2.6 as control (63). Similar results were observed by adding cranberry paste and pumpkin fiber into yoghurt (66). Supplementation of $H$. sabdariffa Calyx extract into the probiotic yoghurt resulted to syneresis 18.85 to $24.90 \mathrm{ml} / 50 \mathrm{gm}$ of sample (65). Yogurts enriched by $H$. polyrhizus resulted a higher syneresis percentage (57.19-70.32 $\%)$ compared to plain yogurt (52.93 \%) (56).

Fig. 3 reveals the impact of $H$. sabdariffa, $H$. polyrhizus and $P$. bivalvis extracts on the Lactobacillus acidophilus viability (log $\mathrm{cfu} / \mathrm{gm}$ ) in the enriched yoghurt. L. acidophilus viability had an increasing trend in the first two weeks and decrease afterwards. Yogurt supplemented with $H$. sabdariffa had the highest $L$. acidophilus viability (11.4-3.7 log $\mathrm{cfu} / \mathrm{gm})$. Meanwhile the control yoghurt had the lowest L. acidophilus viability (11.0-11.6 log $\mathrm{cfu} / \mathrm{gm})$. Bamidele (63) found higher lactic acid bateria 1.2-1.5 $\mathrm{x} 10^{7} \mathrm{cfu} / \mathrm{gm}$ on the day $7^{\text {th }}$ in yoghurt incorporated with $H$. sabdariffa. There were no statistically differences between control and $H$. sabdariffasupplemented groups in terms of lactic acid bacteria (64). $H$. sabdariffa calyx was demonstrated to be beneficial on the quality of $L$. casei incorporated probiotic yoghurt. Yeast and mold proliferation were absent from the Sabdariffa yoghurt (65).

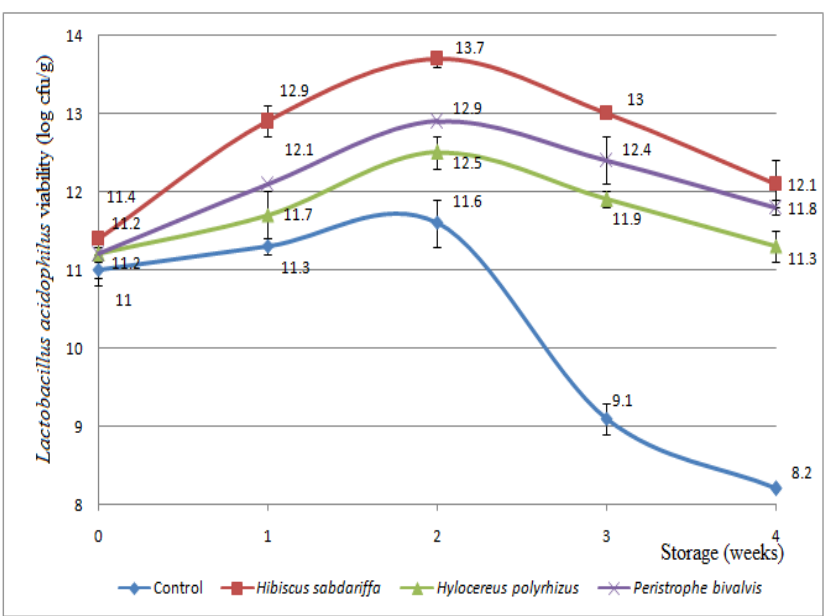

Fig. 3. Lactobacillus acidophilus viability (log cfu/gm) of yoghurt enriched by Hibiscus sabdariffa, Hylocereus polyrhizus, Peristrophe bivalvis extracts.

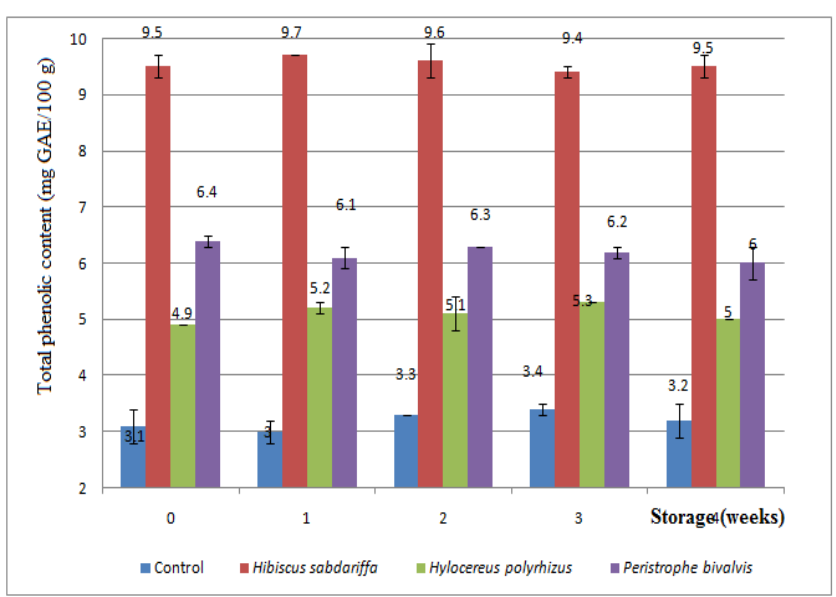

Fig. 4. Total phenolic content (mg GAE/100 gm) of yoghurt enriched by Hibiscus sabdariffa, Hylocereus polyrhizus, Peristrophe bivalvis extracts.

Fig. 4 shows the effect of $H$. sabdariffa and $H$. polyrhizus, $P$. bivalvis extracts on the total phenolic content in the enriched yoghurt. The total phenolic contents were nearly stable during 4 weeks of storage. Yogurt supplemented with $H$. sabdariffa had the highest total phenolic content (9.4-9.7 mg GAE/100 gm). Meanwhile, the control yoghurt had the lowest total phenolic content (3.0-3.4 mg GAE/100 gm). $H$. sabdariffa L. flowers marmalade significantly increased total phenolic content (5.57-14.69 mg GAE/ $100 \mathrm{gm}$ ) of formulated yoghurt (64). H. sabdariffa was reported as an excellent source of antioxidants and total phenolics (67-69). The total phenolic content in the yogurt enriched by $H$. sabdariffa was noticed at $15.21 \mathrm{mg}$ GAE/100 gm (70). Yogurts enriched by $H$. polyrhizus resulted a higher total phenolic content (36.44-64.43mg/ml) compared to plain yogurt $(20.25$ $\mathrm{mg} / \mathrm{ml}$ ) (56). Our results were similar to the findings in another study (71). Yoghurt supplemented with aronia, blueberry and grape juice would receive great advantage of probiotic with excellent phenolic intake.

Fig. 5 shows the effect of $H$. sabdariffa, $H$. polyrhizus and $P$. bivalvis extracts on the antioxidant 


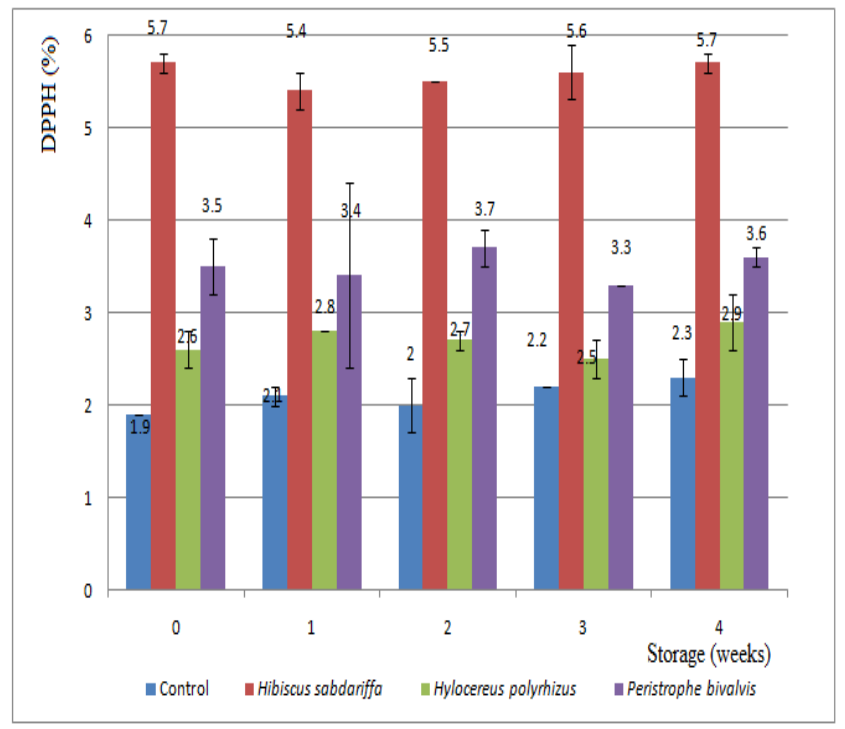

Fig. 5. Antioxidant activity (\%, DPPH) of yoghurt enriched by Hibiscus sabdariffa, Hylocereus polyrhizus, Peristrophe bivalvis extracts.

activity (\%, DPPH) in the enriched yoghurt. The free radical-scavenging activity in the enriched yoghurt were nearly stable during 4 weeks of storage. Yogurt supplementd with $H$. sabdariffa had the highest DPPH (5.4-5.7 \%). Meanwhile, the control yoghurt had the lowest DPPH (1.9-2.3\%). H. sabdariffa L. flowers marmalade significantly increased antioxidant capacity (5.92-26.73 mg TE/100 gm) of formulated yoghurt (64). Supplementation of $H$. Sabdariffa extract in yoghurt enhanced the total antioxidant property with DPPH in range from 12.32 to $59.43 \%$ (65). Yogurts enriched by $H$. polyrhizus resulted a higher antioxidant activity (24.97-45.74 \%) compared to plain yogurt (19.16\%) (56).

\section{Conclusion}

Yoghurt is one of the most common fermented dairy products with a great consumer acceptability due to its functional advantages. There is a trend of using yoghurt incorporated with plant pigments as bioactive constituents that are safe and potential health benefits. In this research, extracts from $H$. polyrhizus, $H$. sabdariffa and $P$. bivalvis were added into yoghurt as functional ingredients. $H$. sabdariffa revealed as a promising candidate to improve total acidity, syneresis, L. acidophilus viability, total phenolic content and free radical-scavenging activity in the enriched yoghurt. Consumer will have more chance to consume one kind of the healthy yoghurt enriched with phytochemical source.

\section{Acknowledgements}

We acknowledged the financial support for the publication provided by Thu Dau Mot University, Binh Duong province, Vietnam.

\section{Authors' contributions}

Nguyen Phuoc Minh arranged the experiments and also wrote the manuscript.

\section{Conflict of interests}

The authors confirmed that this study was conducted without any conflict of interest.

\section{References}

1. Nassim N, Hasanah MG, Anis SMH, Mehrnoush A, Mohd YAM. Characterization and quantification of dragon fruit (Hylocereus polyrhizus) betacyanin pigments extracted by two procedures. Pertanika Journal of Tropical Agriculture Science. 2012;35:33-40.

2. Nazli M, Omid M, Fatemeh S, Shaghayegh M, Seyedeh KT. Introducing a new natural product from dragon fruit into the market. IJRRAS. 2013;15:269-72.

3. Nguyen PM. Various factors influencing to red dragon fruit (Hylocereus polyrhizus) wine fermentation. International Journal of Multidisciplinary Research and Development. 2014;1:94-98. http://www.allsubjectjournal.com/vol1/issue5/PartB/10.html

4. Islam MZ, Khan MTH, Hoque MM, Rahman MM. Studies on the processing and preservation of dragon Fruit (Hylocereus undatus) jelly. The Agriculturists. 2012;10:29-35. https://doi.org/ 10.3329/agric.v10i2.13139

5. Nur-Izalin MZ, Kharidah M, Jamilah B, Noranizan MA Functional properties of pectin from dragon fruit (Hylocereus polyrhizus) peel and its sensory attributes. Journal of Tropical Agricultural and Food Science. 2016;44:95-101.

6. Vergara C, Saavedra J, Sáenz C, García P, Robert P Microencapsulation of pulp and ultrafiltered cactus pear (Opuntia ficus-indica) extracts and betanin stability during storage. Food Chemistry. 2014;157:246-51. https://doi.org/10.1016/j.foodchem.2014.02.037

7. Mello FR, Bernardo C, Dias CO, Gonzaga L, Amante ER, Fett R, Candido LMB. Antioxidant properties, quantification and stability of betalains from pitaya (Hylocereus undatus) peel. Food Technology. 2015;45:323-28. https://doi.org/10.1590/0103 $8478 \mathrm{cr} 20140548$

8. Bao MNN, Tantawan P. Physicochemical properties and antioxidant activities of white dragon fruit peel pectin extracted with conventional and ultrasound-assisted extraction. Cogent Food and Agriculture. 2019;5:1 https://doi.org/10.1080/23311932.2019.1633076

9. Oshadi J., Sumali F., Vijith J. Production of a novel fruityoghurt using dragon fruit (Hylocereus undatus L.). European Scientific Journal. https://eujournal.org/index.php/esj/article/view/4998

10. Zaid RM, Zularisam AW, Mimi SAM. Effect of process parameters on pectin extraction from dragon fruit (Hylocereus polyrhizus) peels via chemical and physical treatment. Australian Journal of Basic and Applied Sciences. 2016;10:6974. http://www.ajbasweb.com/old/ajbas/2016/Special \%20ICCEIB/69-74.pdf

11. Suguna M, Wan-Nadiah WA, Liong MT, Bhat R. Microbial safety of street vended and laboratory prepared dragon-fruit (pitaya) juices in Penang, Malaysia. International Food Research Journal. 2011;18:1509-13. http://www.ifrj.upm.edu.my/18\%20(04)\%202011/(43)IFRJ-2011082.pdf

12. Lin HH, Chen JH, Wang CJ. Chemopreventive properties and molecular mechanisms of the bioactive compounds in Hibiscus sabdarifa Linne. Current Medicinal Chemistry. 2011;18:124554. http://dx.doi.org/10.2174/092986711795029663

13. Grace F, Joseph A, Kwabena OK, Samuel LK, Yaw DF. Potential of aqueous extract of Hibiscus sabdariffa calyces as coloring agent in three pediatric oral pharmaceutical formulations. Journal of Applied Pharmaceutical Science. 2014;4:001-07. http://dx.doi.org/10.7324/JAPS.2014.41201

14. Minh NP. Various variables in production of dried roselle (Hibiscus sabdariffa L.) calyx herbal tea. Bioscience Research. 2020;17:941-47. https://www.isisn.org/BR17(2)2020/941-94717(2)2020BR20-109.pdf 
15. Ghazala R, Rajni C. A review on phytochemistry and therapeutic uses of Hibiscus sabdariffa L. Biomedicine and Pharmacotherapy.

https://doi.org/10.1016/j.biopha.2018.03.023

16. Salleh N, Runnie I, Roach D, Mohamed S, Abeywardena Y. Inhibition of low-density lipoprotein oxidation and upregulation of low-density lipoprotein receptor in HepG2 cells by tropical plant extracts. J Agric Food Chem. 2002;50:3693-97. http://dx.doi.org/10.1021/jf011593f

17. Ali-Bradeldin H, Al-Wabel N, Gerald B. Phytochemical, pharmacological and toxicological aspects of Hibiscus sabdariffa: A review. J Phytotheray Res. 2005;19:369-75. http://dx.doi.org/10.1002/ptr.1628

18. Gaya IB, Mohammad OMA, Suleiman AM, Maje MI, Adekunle AB. Toxicological and lactogenic studies on the seeds of Hibiscus sabdariffa Linn. (Malvaceae) extract on serum prolactin levels of albino wistar rats. The Internet Journal of Endocrinology. https://www.researchgate.net/publication/237150354

2009;5:2.

19. Okoro EC. Production of red wine from roselle (Hibiscus sabdariffa) and pawpaw (Carica papaya) using palm-wine yeast (Saccharomyces cerevisiae). Nigerian Food Journal. 2007; 25:158-64. http://dx.doi.org/10.4314/nifoj.v25i2.50854

20. Tsai PJ, McIntosh J, Pearce P, Camden B, Jordan BR. Anthocyanin and antioxidant capacity in roselle (Hibiscus sabdariffa L.) extract. Food Research International 2002; 35: 351-56. https://doi.org/10.1016/S0963-9969(01)00129-6

21. Ismail A, Ikram EHK, Nazri HSM. Roselle (Hibiscus sabdariffa L.) seeds nutritional composition protein quality and health benefits. $\quad$ Food. 2008;2:1-16. http://www.globalsciencebooks.info/Online/GSBOnline/images/ 0806/FOOD_2(1)/Food_2(1)1-16o.pdf

22. Bako IG, Mabrouk MA, Abubakar A. Antioxidant effect of ethanolic seed extract of Hibiscus sabdariffa Linn. (Malvaceae) alleviate the toxicity induced by chronic administration of sodium nitrate on some haematological parameters in Wistars rats. Advance Journal of Food Science and Technology. 2009;1: 39-42. https://maxwellsci.com/print/ajfst/39-42.pdf

23. Bolade MK, Oluwalana IB, Ojo O. Commercial practice of roselle (Hibiscus sabdariffa L.) beverage production: Optimization of hot water extraction and sweetness level. World Journal of Agricultural Sciences. 2009;5:126-31. http://citeseerx.ist.psu.edu/viewdoc/download?

doi=10.1.1.415.3860\&rep=rep1\&type=pdf

24. Bahaeldeen BM, Abdelatif AS, Abdelhafiz AD. Roselle (Hibiscus sabdariffa L.) in Sudan, cultivation and their uses. Bulletin of Environment, Pharmacology and Life Sciences. 2012;1:48-54. https://www.researchgate.net/publication/321759327_Roselle_ Hibiscus_sabdariffa_L_in_Sudan_Cultivation_and_Their_Uses

25. Maskat MY, Lung CK, Momeny E, Khan MJ, Siddiqui SA. Temperature and feed rate effects properties of spray dried Hibiscus sabdariffa powder. Int J Drug Dev Res. 2014;6:28-34. https://www.ijddr.in/drug-development/temperature-and-feedrate-effects-properties-of-spray-dried-hibiscussabdariffapowder.php?aid=5709

26. Thongam CA, Rocky T, Sylvia MS, Jenita T, Sanasam SS Hibiscus sabdariffa - A natural micro nutrient source. International Journal of Advanced Research in Biological Sciences.

https://ijarbs.com/pdfcopy/apr2016/ijarbs33.pdf

27. Ochoa-Velasco CE, Salazar-Gonzalez C, Cid-Ortega S, GuerreroBeltran JA. Antioxidant characteristics of extracts of Hibiscus sabdariffa calyces encapsulated with mesquite gum. J Food Sci Technol. 2017;54:1747-56. https://link.springer.com/article/10.1007/s13197-017-2564-1

28. Nguyen VQ, Do TK, Luan TD, Truong NM, Nakagoshi N, Tran DX. The Potential use of a food-dyeing plant Peristrophe bivalvis (L.) Merr. in Northern Vietnam. International Journal of Pharmacology, Phytochemistry and Ethnomedicine. 2013;4 14-26. https://doi.org/10.18052/www.scipress.com/IJPPE.4.14

29. Trinh NL, Watson JW, Hue NN, De NN, Minh NV, Chu P, Sthapit BR, Eyzaguirre PB. Agrobiodiversity conservation and development in Vietnamese home gardens. Agr Ecosyst Environ. 2003;97:317-44. https://doi.org/10.1016/S01678809(02)00228-1
30. Yang W, Gu F, Lü J, Yang M. Effect of the extract from Peristrophe roxburghiana on hemorheology in rats. Zhong Yao Cai. 2002;25:727-28. https://pubmed.ncbi.nlm.nih.gov/15562722

31. Cheng Z, Lü J, Liu J. Effects of Peritrophe roxburghiana on blood pressure in renal hypertensive and hyperlipidemic rats. Zhong Yao Cai. 2004;27:927-30. https://europepmc.org/article/ med/15807245

32. Verma RK, Chaurasia L, Katiyar S. Potential antifungal plants for controlling building fungi. Indian J Nat Pro Res. 2008;7: 374-87. http://nopr.niscair.res.in/handle/123456789/5699

33. Wiart C, Mogana S, Khalifah S, Mahan M, Ismail S, Buckle M, Narayana AK, Sulaiman M. Antimicrobial screening of plants used for traditional medicine in the state of Perak, Peninsular $\begin{array}{lll}\text { Malaysia. } & \text { Fitoterapia. }\end{array}$ https://doi.org/10.1016/j.fitote.2003.07.013

34. Hutkins RW. Microbiology and technology of fermented foods. 1st Ed., IFT Press. Blackwell Pub. Ames, Iowa. 2006.

35. Johnson JL, Phelps CF, Cummins CS, London J, Gasser F. Taxonomy of the Lactobacillus acidophilus group. Inter J Sys Bacteriol. 1980;30:53-68. https://doi.org/10.1099/00207713-30-153

36. Holzapfel WH, Schillinger U. Introduction to pre and probiotics. Food Res Intl. 2002;35:109-16. https://doi.org/10.1016/S0963-9969(01)00171-5

37. Marteau P, Boutron-Ruault MC. Nutritional advantages of probiotics and prebiotics. Br J Nutr. 2002;87:153-57. https://doi.org/10.1079/BJNBJN2002531

38. Gilliland SE, Reilly SS, Kim GB, Kim HS. Viability during storage of selected probiotic lactobacilli and bifidobacteria in a yoghurt-like product. J Food Sci. 2002;67:3091-95. https://doi.org/10.1111/j.1365-2621.2002.tb08864.x

39. Lourens-Hattingh A, Viljoen B. Review: Yogurt as probiotic carrier food. Int Dai J. 2001;11:1-17. https://doi.org/10.1016/S0958-6946(01)00036-X

40. Staffolo MD, Bertola N, Martino M, Bevilacgua YA. Influence of dietary fiber addition on sensory and rheological properties of yogurt. Int Dairy J. 2004;14:263-68. https://doi.org/10.1016/j.idairyj.2003.08.004

41. Heyman M. Effect of lactic acid bacteria on diseases. J Am Coll Nutr. https://doi.org/10.1080/07315724.2000.10718084

42. Vesa TH, Marteau, Korpela R. Lactose intolerance J Am Coll Nutr. https://doi.org/10.1080/07315724.2000.10718086

43. Mazahreh AS, Ershidat MO. The benefits of lactic acid bacteria in yoghurt on the gastrointestinal function and health. Pak J Nutr. https://doi.org/10.3923/pjn.2009.1404.1410 2009;8:1404-10

44. Kerry A, Jackson B, Dennis A. Lactose maldigestion, calcium intake and osteoporosis in African, Asian and HispanicAmericans. J Am Coll Nutr. 2001;20:198-205 https://doi.org/10.1080/07315724.2001.10719032

45. Joel N, Felicia I, Rabiu G. Production and quality assessment of functional yoghurt enriched with coconut. Int J Nutr Food Sci. 2014;3:545-50. https://doi.org/10.11648/j.ijnfs.20140306.19

46. Priyanka M, Kempanna C, Narasimha M, Anjum. Quality characteristics of yoghurt enriched with Spirulina powder. Mysore J Agric Sci. 2013;47:354-359.

47. Adriana D, Georgiana GC, Anca-Mihaela G, Lăcrămioara R Quality assessment of yogurt enriched with different types of fibers, CyTA - Journal of Food 2018;16:859-67. https://doi.org/10.1080/19476337.2018.1483970

48. Hashim IB, Khali AH, Afifi HS. Quality characteristics and consumer acceptance of yogurt fortified with date fiber. J Dairy Sci. 2009;92:5403-07. https://doi.org/10.3168/jds.20092234

49. Berrak D, Tulay O. Improving the textural properties of yogurt fortified with milk proteins. J Food Process Preserv. 2017;41:13101. https://doi.org/10.1111/jfpp.13101

50. Henrique J, Giordana DA, Katia R, Vitor CC, Flávio HR, José CCP. Enhancement of antioxidant activity and physicochemical 
properties of yogurt enriched with concentrated strawberry pulp obtained by block freeze concentration. Food Res Int. 2018;104:119-25. https://doi.org/10.1016/j.foodres.2017.10.006

51. Marina J, Marija P, Jelena M, Snezana Z, Jovanka LP, Dragana MC, Stanislava G. Bioactivity and sensory properties of probiotic yogurt fortified with apple pomace flour. Foods. 2020;9:763. https://doi.org/10.3390/foods9060763

52. Tatjana K, Jolanta S, Pawel G. Rheological and textural properties of yogurts enriched with Jerusalem artichoke flour. Czech J Food Sci. 2017;35:432-39. https://doi.org/10.17221/2/2017-CJFS

53. Konstantinos BP, Fani KK, Paschalis EG, Ioannis G, Konstantinos NP, Alexandros CN. Production of novel bioactive yogurt enriched with olive fruit polyphenols. World Acad Sci Engin Technol Int J Nutr Food Eng. 2012;6:170-75.

54. Amove J, Ogori AF, Aondoakaa PI. Effect of yoghurt-milk enrichment with whole soy bean flour. J Nutr Health Food Engin. 2019;9:97-103. https://medcraveonline.com/JNHFE/JNHFE-09-00333.pdf

55. Se-Hyung K, Hyun-Woo L, Jung-Whan C, Kwang-Young S, KunHo S. Sensory profiles of dairy products supplemented with Hibiscus sabdariffa Linnaeus (Roselle) powder: A preliminary study. J Milk Sci Biotechnol. 2019;37:247-55. https://doi.org/10.22424/jmsb.2019.37.4.247

56. Zainoldin $\mathrm{KH}$ and Baba AS. The effect of Hylocereus polyrhizus and Hylocereus undatus on physicochemical, proteolysis and antioxidant activity in yogurt. World Academy of Science, Engineering and Technology. 2009;60:361-66.

57. Weerathilake WADV, Rasika DMD, Ruwanmali JKU, Munasinghe MADD. The evolution, processing, varieties and health benefits of yogurt. International Journal of Scientific and Research Publications. 2014;4:1-10. http://www.ijsrp.org/research-paper-0414/ijsrp-p2855.pdf

58. Sidira M, Santarmaki V, Kiourtzidis M, Argyri AA, Papadopoulou OS, Chorianopoulos N, Tassou C, Kaloutsas S, Galanis A, Kourkoutas Y. Evaluation of immobilized Lactobacillus plantarum 2035 on whey protein as adjunct probiotic culture in yoghurt production. LWT-Food Sci. Technol. https://doi.org/10.1016/j.lwt.2016.08.026

59. Rodrigo OM, Gabriel GN, Rosangelade F, Antônio FC, Luís AN. Enumeration of bifidobacteria using Petrifilm ${ }^{\mathrm{TM}}$ AC in pure cultures and in a fermented milk manufactured with a commercial culture of Streptococcus thermophilus. Food Microbiology.

2011;28:1509-13. https://doi.org/10.1016/j.fm.2011.07.002

60. Arnous A, Makris DP, Kefalas P. Correlation of pigment and flavanol content with antioxidant properties in selected aged regional wines from Greece. J Food Compost Anal. 2002;15: 655-65. http://dx.doi.org/10.1006/jfca.2002.1070

61. Tamime AY, Deeth HC. Yogurt: Technology and biochemistry. J Food Prot 1980;43:939-77. https://doi.org/10.4315/0362 $028 X 43.12 .939$

62. Paramee C, Anchalee S, Arunporn I. Studies on the optimum conditions for the extraction and concentration of Roselle (Hibiscus sabdariffa Linn.) extract. Songklanakarin J Sci Technol. 2008;30:133-39.

63. Bamidele AI. Effect of Hibiscus sabdariffa (Calyce) extract on biochemical and organoleptic properties of yogurt. Pak J Nutr. 2007;6:172-82. http://dx.doi.org/10.3923/pjn.2007.172.182

64. Ayla A, Mehmet AS, Ihsan B. The effects of adding Hibiscus sabdariffa L. flowers marmalade on some quality properties, mineral content and antioxidant activities of yogurt. J Food Sci Technol. 2020;5:1-20. https://doi.org/10.1007/s13197-020-04533

65. Rasdhari M, Parekh T, Dave N, Patel V, Subhash R. Evaluation of various physico-chemical properties of Hibiscus sabdariffa and $L$. casei incorporated probiotic yoghurt. Pak J Biol Sci. 2008;11:2101-08.

http://dx.doi.org/10.3923/pjbs.2008.2101.2108

66. Bakirci S, Dagdemir E, Boran OS, Hayaloglu AA. The effect of pumpkin fibre on quality and storage stability ofreduced-fa set-type yogurt. Int J Food Sci Tech. 2017;52:180-87. https://doi org/10.1111/ijfs.13264

67. Christian KR, Jackson JC. Changes in total phenolic and monomeric anthocyanin composition and antioxidant activity of three varieties of sorrel (Hibiscus sabdariffa) during maturity. J Food Compos Anal. 2009;22:663-67. https://doi.org/10.1016/j. jfca.2009.05.007

68. Mohd-Esa N, Hern FS, Ismail A, Yee CL. Antioxidant activity in different parts of roselle (Hibiscus sabdariffa L.) extracts and potential exploitation of the seeds. Food Chem. 2010;122:105560. https://doi.org/10.1016/j.foodchem.2010.03. 074

69. Riaz G and Chopra R. A review on phytochemistry and therapeutic uses of Hibiscus sabdariffa L. Biomed and Pharmacother. https://doi.org/10.1016/j.biopha.2018.03.023

70. Leyva Daniel DE, Barragan Huerta BE, Vizcarra Mendoza MG Sosa IA. Effect of drying conditions on the retention of phenolic compounds, anthocyanins and antioxidant activity of roselle (Hibiscus sabdariffa L.) added to yogurt. Int J Food Sci Tech. 2013;48:2283-91. https://doi.org/10.1111/ijfs.12215

71. Dimitra D, Nikoletta S, Evangelos K, Panagiotis K. Yoghurts supplemented with juices from grapes and berries. Foods. 2020;9:1158. http://dx.doi.org/10.3390/foods9091158 